\title{
Penerapaan Model Pembelajaran Kooperatif Tipe STAD Sebagai Upaya Meningkatkan Hasil Belajar Matematika Peserta Didik pada Materi Lingkaran di Kelas VI SDN 30/X Kampung Laut T.A 2021/2022
}

\author{
Hasnah \\ SDN 30/X Kampung Laut \\ Jl. K.H. Muhtar, Tanjung Jabung Timur, Jambi, Indonesia \\ hasnah@gmail.com
}

\begin{abstract}
This study aims to describe and obtain information on improving learning outcomes of mathematics content through the STAD type cooperative learning model. This research is classroom action research consisting of two cycles, each cycle consisting of two meetings. Each meeting consists of four stages, namely planning, implementation, observation, and reflection. The subjects of this study were students of class VI SDN 30/X Kampung Laut, totaling 21 people. This research was conducted in the odd semester of the 2021/2022 academic year. Data collection techniques using tests, observations, and documentation. Data were analyzed using percentages. The results of the research show that through the STAD type cooperative learning model can improve the mathematics learning outcomes of sixth grade students at SDN 30/X Kampung Laut by giving rewards.
\end{abstract}

Keywords: Learning outcomes, mathematics, STAD

\begin{abstract}
Abstrak
Penelitian ini bertujuan untuk mendeskripsikan dan mendapatkan informasi peningkatan hasil belajar muatan matematika melalui model pembelajaran kooperatif tipe STAD. Penelitian ini merupakan penelitian tindakan kelas yang terdiri dari dua siklus masing-masing siklus terdiri dari dua kali pertemuan. Masing-masing petemuan terdiri dari empat tahapan yaitu perencanaan, pelaksanaan, observasi dan refleksi. Subjek penelitian ini adalah peserta didik kelas VI SDN 30/X kampung Laut yang berjumlah sebanyak 21 orang. Penelitian ini dilaksanakan pada semseter ganjil tahun ajaran 2021/2022. Teknik pengumpulan data menggunakan tes, observasi, dan dokumentasi. Data dianalisis menggunakan persentase. Hasl penelitian menunjukkan bahwa melalui model pembelajaran kooperatif tipe STAD dapat meningkatkan hasil belajar matematika peserta didik kelas VI SDN 30/X Kampung Laut dengan pemberian reward.
\end{abstract}

Kata kunci: Hasil belajar, matematika, STAD

Copyright (c) 2022 Hasnah

Corresponding author: Hasnah

Email Address: hasnah@gmail.com (Jl. K.H. Muhtar, Tanjung Jabung Timur, Jambi)

Received 10 January 2022, Accepted 20 January 2022, Published 28 January 2022

\section{PENDAHULUAN}

Pendidikan adalah usaha sadar dan terencana untuk mewujudkan suasana belajar dan proses pembelajaran agar peserta didik secara aktif mengembangkan potensi dirinya untuk memiliki kekuatan spiritual keagamaan, pengendalian diri, kepribadian, kecerdasan, akhlak mulia, serta keterampilan yang diperlukan dirinya, masyarakat bangsa dan Negara. Menurut UU Sisdiknas No 20/20023). Pendidikan Nasional adalah suatu usaha untuk mengembangkan kemampuan dan membentuk watak serta peradaban bangsa yang bermartabat dalam rangka mencerdaskan kehidupan bangsa, bertujuan untuk berkembangnya potensi peserta didik agar menjadi manusia yang beriman dan bertaqwa kepada Tuhan yang Maha Esa, berakhlak mulia, sehat, kreatif, mandiri dan menjadi warga negara yang bertanggung jawab. 
Pada dunia pendidikan, sekolah adalah merupakan sarana untuk memperoleh pendidikan yang didalamnya terdapat proses pembelajaran. Proses pembelajaran merupakan interaksiantara guru dan peserta didik. Suatu proses pembelajaran akan dapat mencapai hasil seperti yang diharapkan apabila direncanakan dengan baik. Ada tiga hal yang pokok yang perlu diperhatikan dalam Perencanaan Kegiatan Pembelajaran yaitu mulai dari menyusun perencanaan pembelajaran melaksanakan proses pembelajaran dan melakukan evaluasi. Materi dan cara pembelajaran diwujudkan dalam bentuk silabus, sedangkan cara mengetahui keberhasilan pembelajaran dapat diwujudkan dalam bentuk sistem penilaian. Berdasarkan Undang-Undang Nomor 14 Tahun 2005 tentang Guru dan Dosen. Guru adalah pendidik professional dengan bertugas melaksanakan itu semua serta mendidik, mengajar, membimbing, mengarahkan, melatih, menilai dan mengevaluasi peserta didik pada anak usia dini jalur pendidikan formal, pendidikan dasar dan pendidikan menengah.

Matematika merupakan salah satu mata pelajaran yang mempunyai andil dalam pembentukan peserta didik dan diharapkan melalui mata pelajaran Matematika peserta didik mampu mengembangkan potensinya secara maksimal sehingga bisa menjadi insan yang cerdas, trampil serta kreatif di dalam kehidupan bermasyarakat. Mata pelajaran matematika bertujuan agar peserta didik memiliki kemampuan salah satunya dapat memahami konsep matematika, menjelaskan keterkaitan antarkonsep dan mengaplikasikan konsep atau algoritma, secara luwes, akurat, efisien, dan tepat, dalam pemecahan masalah.

Berdasarkan uraian di atas dapat ditarik kesimpulan bahwa pentingnya pendidikan bagi peserta didik salah satunya pendidikan yang mengajarkan matematika, karena setiap aktifitas kehidupan menggunakan matematika, hal tersebutlah yang membuat matematika adalah mata pelajaran yang utama untuk dipelajari bagi peserta didik dan ini juga dibuktikan sejak duduk dibangku tingkat dasar, peserta didik sudah diajarkan mata pelajaran matematika. Namun pada kenyataannya, sebagian peserta didik menganggap mata pelajaran Matematika merupakan mata pelajaran yang sulit dipahami. Hal ini dapat dilihat berdasarkan hasil nilai ulangan harian mata pelajaran Matematika peserta didik kelas VI SDN 30/X Kampung Laut, Kabupaten Tanjung Jabung Timur yang kurang memuaskan. Dari 21 peserta didik kelas VI, hanya 5 orang atau $24 \%$ yang memperoleh nilai mencapai Kriteria Ketuntasan Minimal (KKM) yaitu 70.

Berdasarkan atas evaluasi peneliti selama mengajar di SDN 30/X Kampung Laut terdapat beberapa kendala dalam pencapaian hasil belajar yang optimal. Dari beberapa kali diberikan penilaian ternyata hasil belajarnya masih tetap rendah walau telah diberikan berbagai metode atau model pembelajaran yang menjadi bidang kajian peneliti ini adalah rendahnya hasil belajar peserta didik untuk mata pelajaran Matematika di SDN 30/X Kampung Laut. Untuk meningkatkan hasil belajar peserta didik tersebut secara maksimal, maka perlu perbaikan model pembelajaran yaitu melalui Model Pembelajaran Kooperatif tipe STAD. Pembelajaran Koopratif Tipe STAD yang dimaksud adalah model pembelajaran yang mempersyaratkan peserta didik membentuk kelompok yang beranggotakan empat orang setiap kelompoknya. Penelitian ini dilakukan untuk memecahkan masalah 
yang selama ini menyebkan guru resah, gelisah dengan banyaknya nilai peserta didik tidak tuntas sesuai dengan nilai ketuntasan minimal (KKM). Padahal guru selama ini telah menerapkan yang namanya Pembelajaran kontekstual, dimana pusat pembelajaran sudah berada pada peserta didik dan guru hanya sebagai pemotifator dan fasilitator. Tujuan penelitian adalah untuk mendskripsikan dan mendapatkan informasi tentang upaya meningkatkan hasil belajar Matematika melalui model pembelajaran kooperatif tipe STAD di kelas VI SDN 30/X Kampung Laut.

Guru adalah instrumen pembelajaran yang utama. Guru bukan hanya sebagai pengantar materi semata ataupun penyaji pelajaran, melainkan juga sebagai fasilitator terjadinya aktivitas belajar di kelas. Begitu pula dengan pengajaran yang efektif adalah pengajaran yang menyediakan kesempatan belajar sendiri bagi peserta didik atau melakukan aktivitas sendiri. Menurut Mulyadi (2002:17) Belajar merupakan suatau proses prubahan tingkah laku yang terjadi berdasarkan ada nya rangsangan dan respon, rangsangan tersebut berasal dari luar kemudian direspon. Tidak hanya perubahan tingkah laku saja tetapi juga dapat berupa keterampilan, dan perubahan pada individu.

Hasil belajar merupakan salah satu hal yang digunakan dalam melihat ketercapaian pembelajaran. Ada beberapa pengertian mengenai hasil belajar yang dikemukan oleh para ahli anatara lain sebagai berikut. Menurut Sudjana (2009:22) hasil belajar adalah kemampuan-kemampuan yang dimiliki peserta didik setelah ia menerima pengalaman belajarnya yakni keterampilan dan kebiasaan, pengetahuan dan pengertian, sikap dan cita-cita. Sedangkan Kunandar (2013:62) mengemukakan bahwa hasil belajar adalah kompetensi atau kemampuan tertentu baik kognitif, afektif maupun psikomotorik yang dicapai atau dikuasai peserta didik setelah mengikuti proses belajar mengajar. Hal ini sejalan dengan Syaodih (2011:102) bahwa hasil belajar merupakan realisasi atau pemekaran dari kecakapan-kecakapan potensial atau kapasitas yang dimiliki oleh seseorang.

Pembelajaran matematika menurut Campbell dalam Linda (2008:6) mengungkapkan bahwa Pembelajaran matematika menekankan kesadaran dan kemampuan untuk berargumen dan berkomunikasi secara matematis, untuk memecahkan masalah dan menerapkan matematika dalam kehidupan para peserta didik sehari-hari. Berdasarkan pendapat di atas, tergambar bahwa kegiatan pembelajaran matematika dilakukan dengan sengaja, atas bimbingan guru untuk membahas suatu permasalahan. Dalam pembelajaran matematika, keaktifan peserta didik sangat berpengaruh dalam rangka memahami konsep secara menyeluruh yang merupakan dasar penting dalam pembelajaran matematika.

Penggunaan model mengajar sangat bergantung pada guru sebagai pemegang manajemen kelas dan sekaligus akan menentukan berhasil tidaknya pencapaian tujuan yang hendak dicapai. Menurut S. Nasution (1987) mengatakan bahwa: "Mengajar belajar adalah kegiatan guru dan murid untuk mencapai tujuan. tertentu. Diduga semakin jelas tujuan semakin jelas kemungkinankemungkinannya ditemukan model yang serasi. Namun tidak ada, pegangan yang pasti cara mendapatkan model mengajar yang paling tepat. Baik tidaknya suatu metode mengajar baru terbukti 
dari hasil belajar murid. Bila hasil belajar murid tercapai, maka, dianggap telah terjadi proses belajar mengajar yang tepat".

Model pembelajaran STAD termasuk model pembelajaran kooperatif. Sebagaimana yang diungkapkan oleh Slavin "pembelajaran kooperatif tipe STAD, peserta didik dikelompokkan dalam kelompok belajar yang beranggotakan empat atau lima orang peserta didik yang merupakan campuran dari kemampuan akademik yang berbeda, sehingga setiap kelompok terdapat peserta didik yang berprestasi tinggi, sedang, dan rendah". Pernyataan di atas senada dengan yang dikemukakan oleh Mohamad (2005) "dalam STAD peserta didik dikelompokkan dalam tim-tim pembelajaran dengan empat orang anggota, anggota tersebut campuran yang ditinjau dari tingkat kinerja, jenis kelamin dan suku". Jadi, model pembelajaran STAD adalah kegiatan belajar kelompok, dan hasil dari diskusi kelompok akan dipertanggung jawabkan secara mandiri oleh setiap peserta didik.

\section{METODE}

\section{Setting Penelitian}

Jenis penelitian ini adalah penelitian tindakan kelas. Penelitian ini dilaksanakan di SDN 30/X Kampung Laut pada semester genap, tahun ajaran 2021/2022. Subjek dalam penelitian ini adalah siswa VI dengan jumlah peserta didik 21 orang. Prosedur penelitian ini meliputi perencanaan, pelaksanaan, pengamatan, dan refleksi. Penelitian ini dilaksanakan dalam dua siklus, masing-masing siklus terdiri dari dua kali pertemuan. Teknik yang digunakan dalam pengumpulan data adalah observasi, tes, catatan lapangan dan dokumentasi. Data dianalisis melalui persentase dan reduksi data.

\section{HASIL DAN DISKUSI}

\section{Siklus I}

a. Perencanaan

Pertemuan Pertama pada siklus 1 dilaksanakan pada hari selasa, tanggal 14 september 2021 di kelas VI SDN 30/X Kampung Laut pada jam 08.00 s/d 11.00. Pertemuan pertama membahas tentang lingkaran, sedangkan indikator pencapaian kompetensi yang diharapkan ialah dapat menjelaskan istilah-istilah yang terkait lingkaran, yaitu titik pusat, jari-jaari, diameter, busur, tali busur, tembereng, dan juring. Bagi peserta didik yang pakaiannya belum rapi, guru menyuruh peserta didik untuk merapikan pakaiannya terlebih dahulu. Pertemuan pertama terdiri dari tiga kegiatan yaitu kegiatan pendahuluan, kegiatan inti dan kegiatan penutup.

Pada kegiatan pendahuluan, guru memberi salam dan menyiapkan peserta didik secara psikis (termasuk berdo'a) dan fisik untuk mengikuti pembelajaran. Peserta didik mengucapkan salam khas sekolah. Kemudian guru mengecek kehadiran peserta didik, lalu guru menginstruksikan peserta didik untuk mempersiapkan buku, alat, dan bahan lainnya untuk mengikuti kegiatan pembelajaran. Pada kegiatan inti Penyajian materi, Setiap pembelajaran dengan menggunakan model ini dimulai dengan penyajian materi oleh guru di dalam kelas. Kegiatan belajar kelompok, Masing-masing kelompok 
berkumpul untuk mempelajari lembar kegiatan atau materi lainnya tentang lingkaran. Dalam kerja kelompok setiap anggota tim harus melakukan yang terbaik untuk timnya, oleh karena itu setiap anggota tim harus bekerja sama, selanjutnya pemeriksaan terhadap hasil kegiatan kelompok. Kegiatan ini dilakukan dengan cara masing-masing perwakilan tim/kelompok membacakan hasil kerja kelompoknya di depan kelas dan kelompok yang lain menanggapinya. Sehingga terciptalah interaksi antara peserta didik, kemudiam peserta didik mengerjakan soal-soal tes secara individual. Setelah akhir satu atau dua periode setelah guru memberikan prensentasi dan sekitar satu atau dua periode praktek tim, para peserta didik akan mengerjakan kuis/tes. Para peserta didik tidak diperbolehkan untuk saling membantu dalam mengerjakan kuis. Sehingga setiap peserta didik bertanggung jawab secara individual untuk memahami materinya, Pemeriksaan hasil tes, Pemeriksaan hasil tes dilakukan oleh guru, dengan cara membuat daftar skor peningkatan setiap individu yang kemudian dimasukkan menjadi skor kelompok.

Pada kegiatan penutup guru memberikan contoh lingkaran dan unsur-unsur lingkaran. Untuk mencek pemahaman mengenai lingkaran, peserta didik diberikan pekerjaan rumah yaitu membuat sendiri beberapa mengenai bendabenda di sekitar yang berhubungan dengan lingkaran dan unsurunsurnya. Guru menugaskan kepada peserta didik untuk mencari informasi ataupun membaca materi tentang lingkaran. Guru dan peserta didik mengakhiri pembelajaran dengan berdoa semoga apa yang telah dipelajari hari ini dapat dipahami lebih baik. Guru merefleksi pembelajaran sebagai acuan perbaikan pada pertemuan selanjutnya.

Pertemuan kedua pada siklus 1 dilaksanakan pada hari Selasa 21 september 2021 di kelas VI SDN 30/X Kampung Laut pada jam pelajaran 08.00 s/d 11.00. Pertemuan kedua membahas tentang lingkaran indicator pencapaian kompetensi yang diharapkan ialah dapat menjelaskan istilah-istilah yang terkait lingkaran, yaitu titik pusat, jari-jari, diameter, busur, tali busur, tembereng, dan juring. Setelah bel masuk berbunyi, seluruh peserta didik masuk ke lokal dan guru memeriksa kesiapan dan kerapian peserta didik. Bagi peserta didik yang pakaiannya belum rapi, guru menyuruh peserta didik untuk merapikan pakaiannya terlebih dahulu. Pertemuan kedua terdir dari tiga kegiatan yaitu kegiatan pendahuluan kegiatan inti dan kegiatan penutup.

Kegiatan pendahuluan terdir dari 5 menit. Pada kegiatn ini guru menyiapkan peserta didik secar psikis (termasuk berdo'a) dan fisik untuk mengikuti proses pembelajaran. Melalui tanya jawab peserta didik diingatkan kembali tentang jenis-jenis lingkaran dan unsur-unsurnya yang telah dipelajari sebelumnya. Guru menjelaskan tujuan pembelajarn yang akan dicapai. Guru menyampaikan ruang lingkup materi dan kompetensi yang akan dicapai. Guru membagi peserta didik menjadi beberapa kelompok yang heterogen yang terdiri dari 4 orang anggota masing-masing kelompok dan terdapat satu kelompok yang berjumlah lima orang karena keseluruhan jumlah peserta didik sebanyak 21 orang.

Pada kegiatan inti ini melibatkan peserta didik mencari informasi yang luas dan dalam tentang topik/tema materi yang akan dipelajari yaitu menjelaskan istilah-istilah yang terkait lingkaran, yaitu 
titik pusat, jari-jari, diameter, busur, tali busur, tembereng, dan juring. Penyajian materi, Setiap pembelajaran dengan menggunakan model ini dimulai dengan penyajian materi oleh guru di dalam kelas. Kegiatan belajar kelompok, masing-masing kelompok berkumpul untuk mempelajari lembar kegiatan atau materi lainnya tentang lingkaran. Dalam kerja kelompok setiap anggota tim harus melakukan yang terbaik untuk timnya, oleh karena itu setiap anggota tim harus bekerja sama, selanjutnya Pemeriksaan terhadap hasil kegiatan kelompok. Kegiatan ini dilakukan dengan cara masing-masing perwakilan tim/kelompok membacakan hasil kerja kelompoknya di depan kelas dan kelompok yang lain menanggapinya. Sehingga terciptalah interaksi antara peserta didik, kemudiam peserta didik Mengerjakan soal-soal tes secara individual, Setelah akhir satu atau dua periode setelah guru memberikan prensentasi dan sekitar satu atau dua periode praktek tim, para peserta didik akan mengerjakan kuis/tes. Para peserta didik tidak diperbolehkan untuk saling membantu dalam mengerjakan kuis. Sehingga setiap peserta didik bertanggung jawab secara individual untuk memahami materinya, Pemeriksaan hasil tes, Pemeriksaan hasil tes dilakukan oleh guru, dengan cara membuat daftar skor peningkatan setiap individu yang kemudian dimasukkan menjadi skor kelompok. Pada kegiatan penutup guru memberikan contoh lingkaran, peserta didik dapat menyimpulkan istilahistilah yang terkait lingkaran, yaitu titik pusat, jari-jaari, diameter, busur, tali busur, tembereng, dan juring. Untuk mencek pemahaman tentang lingkaran, peserta didik diberikan pekerjaan rumah yaitu mengelompokkanbarang-barang yang termasuk lingkaran yang digunkan pada kehidupan sehari-hari. Guru menugaskan kepada peserta didik untuk mencari informasi ataupun membaca materi tentang lingkaran. Guru dan peserta didik mengakhiri pembelajaran dengan berdoa semoga apa yang telah dipelajari hari ini dapat dipahami lebih baik. Guru merefleksi pembelajaran sebagai acuan perbaikan pada pertemuan selanjutnya.

\section{b. Observasi}

Pada akhir proses belajar mengajar peserta didik diberi tes formatif dengan tujuan untuk mengetahui tingkat keberhasilan peserta didik dalam proses belajar mengajar yang telah dilakukan. Pada siklus I, secara garis besar kegiatan belajar mengajar dengan model pembelajaran kooperatif tipe STAD (Student Teams Achievement Division) sudah dilaksanakan dengan baik, walaupun peran guru masih cukup dominan untuk memberikan penjelasan dan arahan. Berikutnya adalah rekapitulasi hasil tes formatif peserta didik seperti terlihat pada tabel berikut.

Tabel 1. Rekapitulasi Hasil Tes Formatif Pada Siklus I

\begin{tabular}{|c|c|c|}
\hline No & Uraian & Hasil \\
\hline 1 & Jumlah Nilai & 1473 \\
\hline 2 & Rata-rata Nilai & 70.14 \\
\hline 3 & Peserta didik Tuntas & 11 \\
\hline 4 & Peserta didik Tidak Tuntas & 10 \\
\hline 5 & Persentase Peserta didik Tuntas & 52 \\
\hline 6 & Persentase Peserta didik Tidak Tuntas & 48 \\
\hline
\end{tabular}


Berdasrkan tabel di atas dapat diSDN 30/X Kampung Laut disimpulkan bahwa rata-rat tes formatif peserta didik sebesar 70,14 masih berada amang batas KKM (70) yang ditentukan, sedangkan persentase ketuntasan peserta didik sebesar 52\% atau 11 orang peserta didik dari 21 orang sudah tuntas belajar, namun hal ini belum mencapai target yang diiginkan yaitu $80 \%$.

c. Refleksi

Tahap refleksi dilaksanakan pada hari Kamis, tanggal 23 september 2021 bertempat di ruangan majelis guru SDN 30/X Kampung Laut dengan dibantu oleh seorang kolaborator yang bernama Masturo, S.Ag. Berdasarkan hasil pengamatan atau observasi, maka dilakukan refleksi terhadap hasil belajar peserta didik setiap pertemuan pada siklus I, dimana perolehan hasilnya belum mencapai KKM yang ditentukan, karena proses pembelajaran belum maksimal. Dalam proses pemebelajaran pada kegiatan ini, setelah peserta didik melakukan presentasi laporan kerjanya, seharusnya guru memperjelas kembali materi yang dibahas oleh peserta didik, tetapi tidak maksimal karena : a) Guru kurang menguasai materi, b) Guru kurang maksimal mengatur setting latihan, menyebabkan peserta didik kurang kerja sama dalam kelompok saat melakukan investigasi, kurang disiplin, kurang bertanggung jawab dan kurang menghargai pendapat orang lain (teman kelompok), c) Guru kurang efektif mengelola kelas, karena peserta didik meribut saat mengemukakan pendapat, menulis laporan dan saat mempresentasikan hasil laporan. Berdasarkan hasil refleksi tersbut maka pada siklus berikutnya peneliti akan lebih efektif lagi mengelola kelas dan dengan tidakan memberikan reward/hadiah kepada peserta didik yang mendapatkan hasil belajar yang sesuai denga target yang diinginkan. Untuk itu penelitian ini dilanjutkan ke siklus berikutnya (Siklus II).

\section{Siklus II}

\section{a. Perencanaan}

Persiapan yang dilakukan pada perencanaan siklus I adalah mempersiapkan silabus, membuat Rencana Pelaksanaan Pembelajaran (RPP) siklus II yang bercirikan pembelajaran menggunakan model STAD. Mempersiapkan bahan ajar. Mempersiapkan media pembelajaran. mempersiapkan soal ulangan harian dan kunci jawaban. mempersiapkan catatan lapangan siklus II. menyiapkan reward/ hadiah.

\section{b. Pelaksanaan}

Pertemuan pertama pada siklus II dilaksanakan pada hari Selasa, tanggal 5 oktober 2021 pada jam $08.00 \mathrm{~s} / \mathrm{d} 11.00$ pada jam pelajaran ke 2 dan 3 dengan materi mambahas tentang lingkaran, sedangkan indikator pencapaian kompetensi nya ialah menejelaskan taksiran keliling dan luas lingkaran. Pertemuan pertama terdiri dari tiga kegiatan yaitu kegiatan pendahuluan, kegiatan inti dan kegiatan penutup. Pada kegiatan pendahuluan peserta didik berdoa untuk memulai mengikuti proses pembelajaran. Guru memperhatikan kesiapan peserta didik sat persatu dari depan kelas untuk mengikuti proses pembelajaran dengan memperhatikan buku-buku dan alat tulis yang akan digunakan peserta didik selama proses pembelajaran di meja peserta didik masing-masing, sikap peserta didik, dan kehadiran peserta didik (fokus pada yang tidak hadir). Guru menumbuhkan rasa ingintahu peserta 
didik sebelum masuk kepada materi pembelajaran. Guru meminta peserta didik untuk mengamati contoh yang diberikan dan bertanya kepada peserta didik tentang lingkaran. Guru menegaskan tujuan yang akan dicapai dan cakupan materi yang akan dipelajari hari ini. Guru memberitahu aspek-aspek yang akan dinilai serta membagi peserta didik dalam kelompok bereampat dan mempersilahkan peserta didik untuk mengatur tempat duduknya dan duduk berdekatan di dalam kelompoknya masingmasing.

Pada kegiatan inti ini guru Melibatkan peserta didik mencari informasi yang luas dan dalam tentangtopik/tema materi yang akan dipelajari tentang contoh perkalian dan operasi bagi dalam kehidupan sehari-hari. Penyajian materi, setiap pembelajaran dengan menggunakan model ini dimulai dengan penyajian materi oleh guru di dalam kelas. Kegiatan belajar kelompok, Masing-masing kelompok berkumpul untuk mempelajari lembar kegiatan atau materi lainnya tentang perkalian dan opearsi bagi bilangan bulat. Dalam kerja kelompok setiap anggota tim harus melakukan yang terbaik untuk timnya, oleh karena itu setiap anggota tim harus bekerja sama, selanjutnya pemeriksaan terhadap hasil kegiatan kelompok. Kegiatan ini dilakukan dengan cara masing-masing perwakilan tim/kelompok membacakan hasil kerja kelompoknya di depan kelas dan kelompok yang lain menanggapinya. Sehingga terciptalah interaksi antara peserta didik, kemudiam peserta didik mengerjakan soal-soal tes secara individual. Setelah akhir satu atau dua periode setelah guru memberikan prensentasi dan sekitar satu atau dua periode praktek tim, para peserta didik akan mengerjakan kuis/tes. Para peserta didik tidak diperbolehkan untuk saling membantu dalam mengerjakan kuis. Sehingga setiap peserta didik bertanggung jawab secara individual untuk memahami materinya, Pemeriksaan hasil tes, Pemeriksaan hasil tes dilakukan oleh guru, dengan cara membuat daftar skor peningkatan setiap individu yang kemudian dimasukkan menjadi skor kelompok. Penghargaan kelompok, Tim/kelompok akan mendapat sertifikat atau bentuk penghargaan yang lain apabila skor rata-rata mereka mencapai kriteria tertentu.

Pada kegiatan penutup dilakukan tanya jawab dengan bimbingan guru membuat kesimpulan mengenai linkaran yag di dalamnya membahas luas dan keliling lingkaran, kesimpulan tersebut diantaranya: 1). Apa itu luas lingkaran? 2). Apa itu keliling lingkaran?. Guru meminta peserta didik untuk menyimpan semua buku ke dalam tas. Guru melakukan refleksi dengan meminta pendapat peserta didik mengenai proses pembelajaran yang telah dilakukan. Guru mengakhiri pembelajaran dengan berdoa diiringi peserta didik dan berharap semoga apa yang telah dipelajari dapat dipahami dengan baik dan bermanfaat. Pertemuan kedua pada siklus II dilaksanakan pada hari Selasa, tanggal 12 oktober 2021 jam $08.00 \mathrm{~s} / \mathrm{d} 11.00$ dengan materi tentang lingkaran, sedangkan indicator pencapaian kompetensi yang diharapkan ialah dapat memahami hubungan antara jari-jari dengan diameter. Pertemuan kedua terdiri dari tiga kegiatan yaitu, kegatan pendahuluan, kegiatan inti dan kegiatan penutup.

Guru membuka pelajaran dengan mengucapkan salam pada peserta didik. Guru lalu mengabsen dan menanyakan kondisi peserta didik apakah kesehatan peserta didik baik-baik saja pada 
pagi itu. Kemudian, guru melakukan apersepsi tentang lingkaran yang berhubungan dengan jari-jari dan diameter. Selanjutnya guru menanyakan informsi untuk menentukan sifat-sifat apa saja yang terdapat pada lingkaran.

Pada kegiatan inti ini Setiap pembelajaran dengan menggunakan model ini dimulai dengan penyajian materi oleh guru di dalam kelas. Kegiatan belajar kelompok, Masing-masing kelompok berkumpul untuk mempelajari lembar kegiatan atau materi lainnya tentangjari-jari lingkaran dan diameter. Dalam kerja kelompok setiap anggota tim harus melakukan yang terbaik untuk timnya, oleh karena itu setiap anggota tim harus bekerja sama, selanjutnya pemeriksaan terhadap hasil kegiatan kelompok, kegiatan ini dilakukan dengan cara masing-masing perwakilan tim/kelompok membacakan hasil kerja kelompoknya di depan kelas dan kelompok yang lain menanggapinya. Sehingga terciptalah interaksi antara peserta didik, kemudiam peserta didik mengerjakan soal-soal tes secara individual.

Setelah akhir satu atau dua periode setelah guru memberikan prensentasi dan sekitar satu atau dua periode praktek tim, para peserta didik akan mengerjakan kuis/tes. Para peserta didik tidak diperbolehkan untuk saling membantu dalam mengerjakan kuis. Sehingga setiap peserta didik bertanggung jawab secara individual untuk memahami materinya, Pemeriksaan hasil tes, Pemeriksaan hasil tes dilakukan oleh guru, dengan cara membuat daftar skor peningkatan setiap individu yang kemudian dimasukkan menjadi skor kelompok, Penghargaan kelompok, Tim/kelompok akan mendapat sertifikat atau bentuk penghargaan yang lain apabila skor rata-rata mereka mencapai kriteria tertentu.

Pada kegiatan penutup, guru bersama-sama dengan peserta didik dan/atau sendiri membuat rangkuman/simpulan pelajaran. Melakukan penilaian dan/atau refleksi terhadap kegiatan yang sudah dilaksanakan secara konsisten dan terprogram. Kemudian memberikan umpan balik terhadap proses dan hasil pembelajaran. Lalu merencanakan kegiatan tindak lanjut dalam bentuk pembelajaran remedi, program pengayaan, layanan konseling dan/atau memberikan tugas baik tugas individual maupun kelompok sesuai dengan hasil belajar peserta didik.

c. Observasi

Pada akhir proses belajar mengajar peserta didik diberi tes formatif II dengan tujuan untuk mengetahui tingkat keberhasilan peserta didik selama proses belajar mengajar yang telah dilakukan. Instrumen yang digunakan adalah tes formatif II. Adapun data hasil penelitian pada siklus II adalah sebagai berikut.

Tabel 2. Rekapitulasi Hasil Tes Formatif Pada Siklus II

\begin{tabular}{|c|c|c|}
\hline No & Uraian & Hasil \\
\hline 1 & Jumlah Nilai & 1600 \\
\hline 2 & Rata-rata Nilai & 76.19 \\
\hline 3 & Peserta didik Tuntas & 19 \\
\hline 4 & Peserta didik Tidak Tuntas & 2 \\
\hline 5 & Persentase Peserta didik Tuntas & 90 \\
\hline 6 & Persentase Peserta didik Tidak Tuntas & 10 \\
\hline
\end{tabular}


Berdasarkan tabel di atas dapat disimpulkan bahwa rata-rata tes formatif peserta didik pada pertemuan siklus II sudah berada di atas kriteria ketuntasan yang diharapkan atau sudah berada di atas KKM yang ditetapkan dengan rata-rata yang didapat yaitu sebesar 76,19 dengan persentase ketuntasan sebesar $90 \%$ atau 19 orang dari 21 orang peserta didik yang sudah tuntas belajar.

d. Refleksi

Tahap refleksi siklus II dilaksanakn pad hari Kamis, tanggal 14 Oktober 2021 bertempat di ruangan majelis guru SDN 30/X Kampung Laut dengan dibatu oleh seorang observer yang bernama Masturo, S.Ag. Berdasarkan hasil pengamatan (observasi) peneliti dengan observer dapat dideskripsikan bahwa pelaksanaan pembelajaran Matematika dengan menggunakan model STAD pada siklus II dapat meningkatkan hasil belajar peserta didik degan tindakan memberikan pujian. Berdasarkan refleksi tersebut, diharapkan kepada guru di SDN 30/X Kampung Laut dapat menerapkan model ini dalam proses pembelajaran agar hasil yang dicapai lebih maksimal. Peneliti mengakhiri penelitian ini dengan perolehan hasil yang lebih baik. Karena hasil yang diperoleh sudah melebihi Kriteria Ketuntasan Minimal yaitu 70.

\section{Diskusi}

Melalui hasil peneilitian ini menunjukkan bahwa model pembelajaran kooperatif tipe STAD (Student Teams Achievement Division) dapat meningkatkan hasil belajar matematika peserta didik. Hal ini dapat dilihat dari semakin mantapnya pemahaman peserta didik terhadap materi yang disampaikan guru (ketuntasan belajar meningkat dari siklus I, dan II yaitu masing-masing 52\% dan 90\%. Pada siklus II ketuntasan belajar peserta didik secara klasikal telah tercapai. Untuk lebih jelas dapat dilihat pada diagram berikut ini:

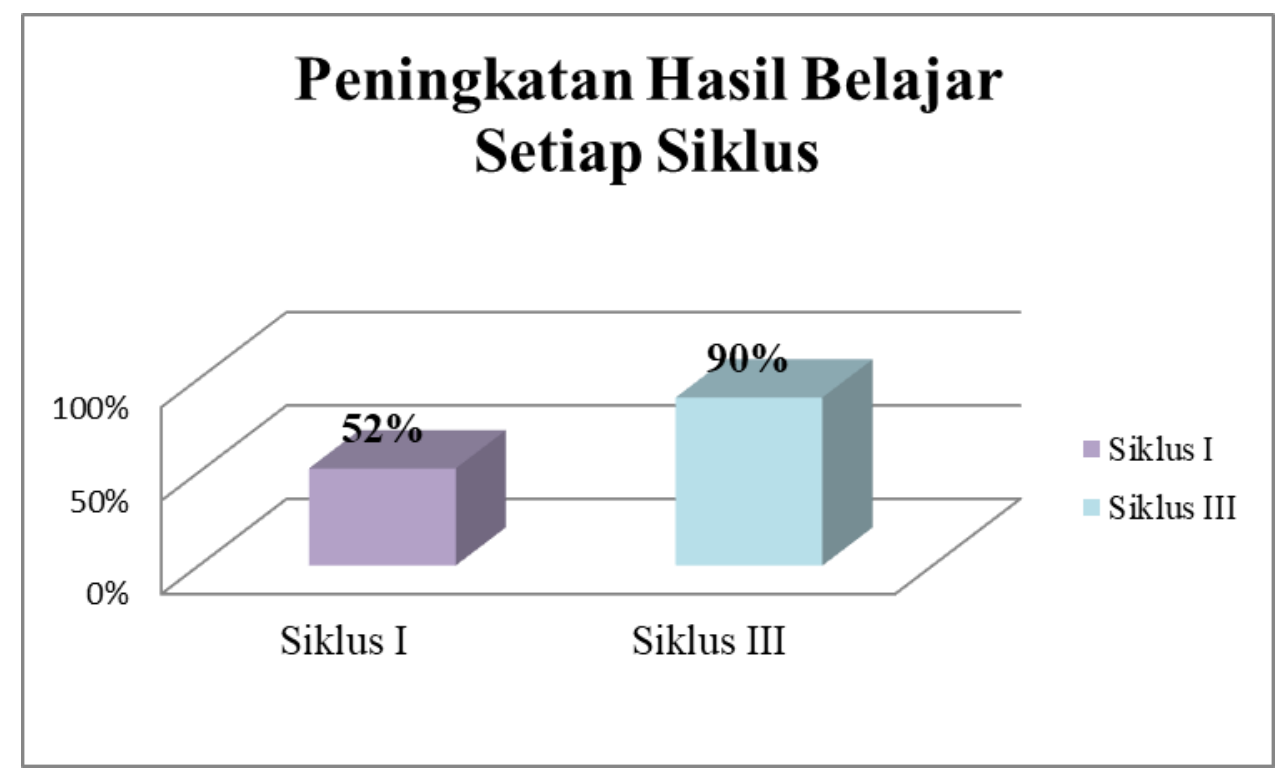

Gambar 1. Pencapaian KKM Klasikal

Sedangkan untuk aktivitas guru selama pembelajaran telah melaksanakan langah-langkah model pembelajaran kooperatif tipe STAD (Student Teams Achievement Division) dengan baik. Hal 
ini terlihat dari aktivitas guru yang muncul di antaranya memotivasi peserta didik, membimbing dan mengamati peserta didik dalam menemukan konsep, dimana prosentase untuk aktivitas di atas cukup besar.

\section{KESIMPULAN}

Dari hasil kegiatan pembelajaran yang telah dilakukan selama dua siklus, dan berdasarkan seluruh pembahasan serta analisis yang telah dilakukan dapat disimpulkan bahwa melalui model pembelajarn kooperatif tipe student team achievment division dapat meningkatkan hasil belajar Matematika peserta didik kelas VI SDN 30/X Kampung Laut yang ditandai dengan peningkatan dari masing-masing siklus yaitu siklus I 52\% dan siklus II 90\%.

Dari hasil penelitian yang diperoleh dari uraian sebelumnya agar proses belajar pembelajaran Matematika lebih efektif dan lebih memberikan hasil yang optimal bagi peserta didik, maka disampaikan saran yaitu untuk melaksanakan model pembelajaran kooperatif tipe STAD (Student Teams Achievement Division) memerlukan persiapan yang cukup matang, sehingga guru harus mempu menentukan atau memilih topik yang benar-benar bisa diterapkan dengan model pembelajaran kooperatif tipe STAD (Student Teams Achievement Division) dalam proses belajar mengajar sehingga diperoleh hasil yang optimal. Kemudian dalam rangka meningkatkan hasil belajar peserta didik, guru hendaknya lebih sering melatih peserta didik dengan berbagai media pengajaran, walau dalam taraf yang sederhana, dimana peserta didik nantinya dapat menemukan pengetahuan baru, memperoleh konsep dan keterampilan, sehingga peserta didik berhasil atau mampu memecahkan masalah-masalah yang dihadapinya. Lalu perlu adanya penelitian yang lebih lanjut, karena hasil penelitian ini hanya dilakukan di SDN 30/X Kampung Laut. Selain itu penelitian yang serupa hendaknya dilakukan perbaikan-perbaikan agar diperoleh hasil yang lebih baik.

\section{UCAPAN TERIMA KASIH}

Ucapan terima kasih sangat layak disampaikan untuk semua pihak yang telah membantu dalam pengerjaan artikel ini. Baik teman, dosen, kakak, dan yang lainnya. Artikel ini dapat dibuat karena adanya bantuan mereka. Semoga artikel ini dapat bermanfaaat untuk banyak pihak.

\section{REFERENSI}

Ades, Sanjaya. 2011. Model-model Pembelajaran. Jakarta: Bumi Aksara.

Agus, Suprijono. 2012. Cooperative Learning: Teori dan Aplikasi Paikem. Yogyakrta: Pustaka Pelajar A.M Sardiman. 2009. Interaksi dan Motivasi Belajar Mengajar. Jakarta: PT. Rajawali. Pers.

Anita Lie. 2002. Cooperative Learning (Memperaktikan Cooperative Learning di Ruang Kelas). Jakarta: PT Gramedia

Arikunto, Suhardjono, dan Supardi. 2011. Penelitian Tindakan Kelas. Jakarta: $\quad$ PT. Bumi Aksara Arsyad, Azhar. 2013. Media Pembelajaran. Jakarta: Rajawali Pers.

Darsono, Max. 2000. Belajar dan Pembelajaran. Semarang: CV. IKIP Semarang Press 
Penerapaan Model Pembelajaran Kooperatif Tipe STAD Sebagai Upaya Meningkatkan Hasil Belajar Matematika

Kunandar. 2013. Penilaian Autentik (Penilaian Hasil Belajar Peserta Didik berdasarkan Kurikulum 2013). Jakarta: Raja Grafindo Persada

Mulyadi. 2002. Auditing, Edisi keenam, Cetakan pertama. Jakarta: Salemba

Nana Syaodih Sukmadinata. 2005. Landasan Psikologi Proses Pendidikan. Bandung: PT Rosda Karya.

Permendiknas Nomor 22 Tahun 2006 tantang Standar Isi

Rusman, 2012. Model-model Pembelajaran. Bandung: Seri manajemen Sekolah Bermutu.

Slameto. 2010. Belajar dan Faktor-Faktor yang Mempengaruhinya. Jakarta: Rineka Cipta

Slavin, robert E. 2009. Cooperative Learning (Teori, Riset, Praktik). Bandung: Nusa Media.

Sudjana Nana. 2002. Penilaian Hasil Proses Belajar Mengajar. Bandung: Remaja Rosdakarya

Sudjana, Nana. 2009. Penilaian Hasil Proses Belajar Mengajar. Bandung: PT. Remaja Rosdakarya.

Trianto. 2009. Mendesain model pembelajaran inovatif-progresif. Jakarta: Kencana Prenada Media Group.

Trianto. 2012. Model Pembelajaran Terpadu. Jakarta: PT Bumi Aksara.

Undang-Undang Nomor 14 Tahun 2005 tentang Guru dan Dosen

Wina Sanjaya. 2007. Strategi Pembelajaran Berorientasi Standar Proses Pendidikan. Jakarta: Kencana Prenada Media Group.

Wina Sanjaya. 2009. Strategi Pembelajaran. Jakarta: Kencana. 